\title{
THE INFLUENCE OF A FIRM'S CSR INITIATIVES ON BRAND LOYALTY AND BRAND IMAGE
}

\section{- Jintao Lu, Licheng Ren, Chong Zhang, Chunyan Wang, Zabra Shabid, Justas Streimikis}

\begin{abstract}
The objective of this study is to examine the impact of corporate social responsibility (CSR) initiatives of a firm as one of the critical factors to improve the competitiveness of the firm in today's aggressive market environment. The influence of corporate social responsibility on brand loyalty and brand image, which distinguishes the firm from other competitors, was evaluated in the study. Data from 364 consumers were collected through adapted and structured questionnaires for the period from August 2018 to December 2018. The respondents were selected through convenience sampling to generate the responses of individual online consumers who buy luxury goods online. The sample size of 364 was taken from a simple random table with a 5\% margin of error and a 95\% confidence level. SEM-based multivariate approaches such as structural equation modeling and confirmatory factor analysis were employed, and SmartPLS 3.0 software was used for the data evaluation. The results indicate that the firm's CSR initiatives have a significant and positive impact on brand loyalty and brand image. The study undertaken has several theoretical and practical implications which could provide the basic foundations and conceptual framework for future studies, and it offers strategic directions for the senior managers of firms to plan CSR initiatives that can enhance the brand loyalty of their brands and also increase corporate reputation, all of which are beneficial to remain competitive in today's business arena.
\end{abstract}

Keywords: Corporate social responsibility, Brand loyalty, Brand image, Competitiveness, SEM-based multivariate approach

JEL Classification: Q01, Q35, Q51

Received: December, 2019

1st Revision: April, 2020

Accepted: May, 2020

\section{INTRODUCTION}

One recent report by Penguin has shown that as for the brand loyalty of cell-phone users, Huawei accounted for the highest proportion in China at a loyalty rate of $62.2 \%$. The main reason indicated in the survey for the repeat purchase of the mentioned brand was that consumers had user experience with the products and had generated strong feelings of attachment to the brand. More than $30 \%$ of regular Internet users in the study chose to support the brand continuously 
because of its domestic brand image (Penguin Intelligence, 2019). High product sales and market share have resulted partly from this consumer loyalty and brand image. Studies have shown that brand loyalty is a vital measurement dimension of brand equity (Taodocs.com, 2019). Brand image, which to a certain extent can even affect the direction of market development, also affects the purchase willingness of consumers as an important influencing factor of their identification with the product (Jia, 2019). Nevertheless, the establishment of brand image and brand loyalty is not so easy, and enterprises should implement corporate social responsibility (CSR) and other practical activities to build trust, improve consumer satisfaction and as such enhance consumer loyalty to their brands (Ahmed et al., 2020; Sürücü et al., 2019). Studies have highlighted the positive effects of consumer-perceived brand innovation (Pappu \& Quester, 2016), brand participation (Leckie et al., 2016), and brand value (Yeh et al., 2016) on brand loyalty. In addition, customer satisfaction (Hew et al., 2016), consumer-perceived corporate reputation (Loureiro et al., 2017), and social media marketing (Ismail, 2017) could improve brand loyalty. As for brand image, consumer perception of brand ethics (Ahmed et al., 2020; Iglesias et al., 2019), consistency of advertising and brand promotion (Arbouw et al., 2019), as well as brand reputation and consumer trust all may create a positive impact on the overall corporate image (Lu et al., 2020; Li et al., 2017). Most of these studies cited have been based on the brand of the enterprise itself in the consideration of the impact of consumer perception and product quality on brand loyalty and brand image. Furthermore, the studies have shown that the CSR performance of a company could help in bringing higher stock returns (Lins et al., 2017), which are in turn favorable for brand reputation (Asmussen \& Fosfuri, 2019).

Scholars have provided various definitions of CSR. According to Kotler \& Lee (2004; 2005), CSR can be defined as the assurance or commitment towards the community for its well-being and welfare, and this objective may be achieved with the help of flexible business practices in the use of corporate resources. Focusing on public welfare activities, Kotler \& Lee $(2004 ; 2005)$ have divided the approaches of CSR implementation into specific types. Other scholars have employed this established structure to explore the influencing mechanisms of CSR on brand loyalty and brand image. For example, Howie et al. (2018) found that public welfare-related marketing affected consumer evaluation of a company, Lu et al. (2020) as well as Nickerson \& Goby (2016) determined corporate social marketing affected the consumer purchase intentions. Yuan \& Tian (2015) found that the amount of corporate philanthropy changed consumer brand attitudes, etc.

Keeping all this in mind, the significance and novelty of this study are hereby indicated. First, this kind of research has been carried out in the Pakistani context in terms of the Belt and Road Initiative (BRI) program, which represents the global development strategy initiated by the Chinese government. The related conclusions can also be applied to countries along the BRI route. Second, it is unique that the present study provides a novel conceptual \& theoretical model, one which the researchers deem is highly relevant for future studies and new investigators, providing the foundation for future studies to replicate these results in different geographical regions and various industries. Third, the research undertaken may serve as a potential source of practical strategies for the CSR initiatives of local industries, i.e. it provides potential strategic directions to the senior managers of business firms to plan their own initiatives. These CSR initiatives can 
enhance the loyalty of their brands and also increase brand image, two factors crucial for enterprises to remain competitive in today's business environment.

The remainder of the paper contains the following: section 2 comprises a literature review and research hypotheses; section 3 discusses methodology and data sources; section 4 elaborates on the results and provides a discussion; and finally, section 5 puts forth conclusions.

\section{LITERATURE REVIEW AND RESEARCH HYPOTHESES}

\subsection{Theories of CSR}

CSR represents a firm's responsibility towards society. It comprises activities that are not only beneficial for society only but also for the firm itself. Firms which are engaged in CSR practices believe that their revenues have increased over time due to this engagement, which has proved helpful for the long-term profit maximization of firms (Lu et al., 2019). Moreover, firms believe that it helps in strengthening their overall image in society among their stakeholders, consumers, and investors, etc. Apart from corporate image, CSR also helps to positively influence the brand loyalty of their consumers. Studies have shown that individuals are more attracted to firms that appear more socially responsible (Irshad et al., 2017), an image that helps improve consumer behavior and purchase intention for the product brand. According to Lu et al., 2019, the CSR activities of a firm play an integral part in building trust among the consumers.

Quite a few theories have come and gone in the evolution of CSR. The main aim of Instrumental Theory is to achieve monetary objectives through social activities. It considers maximizing the value of shareholders on a long-term basis and formulating strategies for competitive advantage through which the corporations can invest in the social arena, i.e. focusing on cause-related marketing as a marketing tool. Political Theory focuses on using the power of the business responsibly in the political arena (Dennis et al., 2017). The social power a firm has is designated by the overall degree of responsibility the enterprise has to society. Integrative Theories focus on management, public, and other stakeholder issues, responsibility, corporate social performance, as well as how corporations respond to social, political, and public issues. Ethical Theory considers the maintenance of principled practices, with the main focus centering on human rights along with the environment and labor rights. Universal rights and the sustainable development of the society associated with a firm are considered, with the main overall objective being the common good of society. This theory has wide applications in CSR literature (Özbağ, 2018). According to Kotler \& Lee (2005), certain CSR initiatives can help enhance the branding aspects of a product or service. The researchers explicate the phenomena of doing good, not considering it as merely an obligation but rather taking it as a welcome responsibility to society and its institutions. CSR initiatives represent a number of activities that firms can adopt and commit to in order to support or eradicate social ills. (Wu \& Wang, 2014). The positive and negative causes firms can take on are mostly related to community development, safety, health, education and employment, environment, basic human rights, and economic development (Dennis et al., 2017). The type of support from the corporations may vary from cash grants to paid advertisements, sponsorship, publicity, employee volunteering, etc. 


\subsection{The impact of CSR on brand loyalty}

Sharma \& Jain (2019) conducted a study showing that people were more likely to respond to a brand that was involved in some good causes. The consumer's idea about a firm depends on perception, which includes brand performance and brand equity. Moreover, brand performance is the input of a brand which influences positively the overall performance of the business (Loosemore \& Lim, 2018; Irshad et al., 2017). To succeed in achieving brand loyalty in the current period, firms must devote attention to creation and sustaining customer loyalty, with CSR having been shown to be a useful tool in this regard (Almeida \& Coelho, 2019). Singh \& Saini (2016) have indicated how consumer loyalty represents the desire of consumers to use a firm's brand, product, or services over time. Kotler et al. (2018) have described the repeat-buying behavior of consumers, which is a sign of brand loyalty.

Enterprises can improve public welfare and CSR implementation through marketing activities as well. As the first of six types of public welfare marketing approaches put forward by Kotler, the cause-related promotion strategies of a firm seek to encourage the public to devote their attention to public welfare causes with the use of the firm's various material or non-material resources (Jeon \& An, 2019; Luo, 2015; Park et al., 2017). The second type is cause-related marketing, i.e. linking donations to certain public welfare causes based on product sales, or donating part of the turnover of product sales. These kinds of activities help realize the brand objectives (Westberg \& Pope, 2014), encouraging consumers to believe the company is ethical and socially responsible (Nan \& Heo, 2007). The third type is corporate social marketing, which refers to planning or facilitating the implementation of certain behaviors to improve the safety, environment, or welfare of a society (Lake \& Conduit, 2016). The fourth type is corporate philanthropy, which refers to direct donations to certain charitable organizations through funds, non-funds, or some kind of services. To obtain public trustworthiness, enterprises usually cooperate with the government or public welfare social organizations to make donations according to the rules stipulated in the Law of the People's Republic of China on Public Welfare Donations. Studies found that corporate philanthropy positively affected customers' attitude towards a company, and that philanthropic marketing had a more significant impact on the purchase behavior of consumers (Tian et al., 2016). The fifth type is community volunteering, which means an enterprise, can encourage and support its employees, partners such as upstream suppliers and downstream retailers to contribute to social activities (Chen, 2018; Liu \& Zhou, 2015; Lu et al., 2019). The sixth type is a responsible business practice, which indicates that enterprises employ means of business practice or investment to support the activities that can improve community welfare and environmental protection. This type of approach firstly can strengthen the connection between enterprises and the stakeholders, help enterprises to obtain knowledge and information, and enhance their ability to use the information (Zhang et al., 2015). Secondly, it can strengthen the sense of belonging of employees and make them contribute more innovations to the company; finally, consumers' preference for the corporate brand is closely related to corporate performance (Zheng, 2014). Consumers will support product brands with CSR through their purchasing behavior (Sen et al., 2016). So, enterprises should be aware of the importance of implementation of the CSR activities, and improve their brand satisfaction (Abbes et al., 2020) and brand identity (Luo \& Jiang, 2019) through consumer brand participation (Kaur et al., 2020), and thus actively influencing brand loyalty of consumers. 
Based on the above analysis, the following hypotheses were proposed:

H1a: Cause promotion has a positive effect on brand loyalty;

H1b: Cause-related marketing has a positive effect on brand loyalty;

H1c: Corporate social marketing has a positive effect on brand loyalty;

H1d: Corporate philanthropy has a positive effect on brand loyalty;

H1e: Community volunteering has a positive effect on brand loyalty;

H1f: Socially responsible business practice has a positive effect on brand loyalty.

\subsection{The impact of CSR on brand image}

According to Almeida \& Coelho (2019), the positive corporate image gives a firm a lot of benefits, including recognition and recall of the brands, brand loyalty, employee motivation and loyalty, and a positive reputation among competitors. There are five elements of corporate image according to Nguyen \& Leblanc (2001). Corporate identity is the very first element, which includes the firm's logo, name, features, price, and communication, esp. advertising. The second element is individuality, which includes the corporate philosophy, corporate culture, values, mission, and the objectives of the firm. The fourth element is the personnel. The personnel of a firm should be friendly, well-educated with the knowledge of product and service offered by the firm, courteous, friendly, with attractive personality and appearance. The fifth element is the environment of the firm (Loosemore \& Lim, 2018; Irshad et al., 2017), which includes the ambiance, aesthetics, buildings, and decors. Wu \& Wang (2014) suggested that firms with good CSR usually had higher returns and profits. Kotler \& Lee (2005) suggested CSR as a commitment to society. As per Loosemore \& Lim (2018), there were four dimensions of CSR that can be explained with the help of a pyramid: economic responsibility, legal responsibility, ethical responsibility, and philanthropic responsibility. Therefore, CSR has a deep and positive impact on corporate image and reputation (Lu et al., 2019). Studies further found that consumers' participating in charitable donations through the CSR activities organized by enterprises could help to improve the image of product brands (Luo \& Lv,2019). Charitable donations had a greater effect on consumers' evaluation of an enterprise than business sponsorship (Liu, 2014). They had an effect on consumers' continuous purchasing willingness (Feng et al., 2019), which could enhance the perception of consumers to corporate reputation (Szőcs et al., 2016). Similarly, the volunteer activities of an enterprise also had a positive impact on the corporate image (Plewa et al., 2015). Enterprises can effectively combine society, economy, and employees by organizing and implementing volunteer activities (Zhou \& Lu, 2011). Therefore, enterprises should actively organize the CSR activities to make consumers perceive the CSR (Dawood,2019) and thus affecting the corporate brand image. Based on the above analysis, the following hypotheses were proposed:

H2a: Cause promotion has a positive effect on brand image;

H2b: Cause-related marketing has a positive effect on brand image;

H2c: Corporate social marketing has a positive effect on brand image;

H2d: Corporate philanthropy has a positive effect on brand image; 
H2e: Community volunteering has a positive effect on brand image;

H2f: Socially responsible business practice has a positive effect on brand image.

\subsection{The impact of brand loyalty on brand image}

Brand loyalty, as the component of the core value of an enterprise, is mainly composed of the attitude and behavior of consumers. The consumers' motivation for CSR and their perception of corporate brands (Mody et al., 2017), and consumer satisfaction (Yang et al., 2017) are important factors affecting consumer loyalty (Yang \& Yin,2019). Companies can employ social media to actively spread the appropriate information of the brand image to consumers (Cheung et al., 2019), and to significantly influence the consumers' perception of the brand agreement with them by conveying the consistency of brand image. The similarity of brand personality and the authenticity of brand extension (Sattayawaksakul et al., 2019). With technological development in recent years, consumers come to choose the products which can meet their brand demands, so a good brand image for an enterprise is the key to successful marketing (Ogba \& Tan, 2009; Ramli, 2017). When consumers have brand awareness, the value of the brand makes consumers remain loyal to the products, and thus positively influencing the brand identity and increasing brand equity (Shabbir et al., 2017). Studies on automobile brands by Mabkhot et al. (2017) found that there was a significant relationship between brand image and brand loyalty. According to the above analysis, there is a meaningful relationship between brand loyalty and brand image. The following hypothesis was proposed:

H3: Brand loyalty positively affects brand image.

\section{METHODOLOGY AND DATA SOURCE}

The study identified the impact of a company's various CSR initiatives on brand loyalty. Further, variables were tested to determine the relationship and correlation among them. The study was based on a positivist approach of philosophy because we are deducing the pre-identified variables through the literature and further creating a generalized idea about these pre-defined variables. This study is quantitative, and the data was employed with deductive analysis. The hypotheses of this study were deduced and then tested. The data were collected with the help of a predeveloped survey questionnaire that was developed on a Likert scale with close-ended questions. The measurement instrument was developed through Kotler \& Lee (2005) for the CSR initiatives, Brand loyalty (Medzhybovska \& Lew, 2019; Sharma \& Jain, 2019), and Brand image (Wu \& Wang, 2014). The mono-method approach was applied to this cross-sectional research to analyze the information which was gathered from different stakeholders that exist in society (Lu et al., 2019). The measurement scale for the CSR initiatives are derived from the previous literature Jeon \& An, 2019; Almeida \& Coelho, 2019; Suki \& Suki, 2019; García-Fernández et al., 2018).

However, the methodology used has certain limitations, such as using the online method to obtain the responses that are not very much appropriate to validate the stipulation of respondents. The geographic scope is also minimal. It is recommended for future studies to increase the geographic scope for more robust results. Finally, the used statistical method does not explain the cause and effect. Therefore, it is suggested to the future researchers to use the model that also 
explains the cause and effects between the independent and dependent variables.

The data was collected through a 5-point Likert scale based on the structured questionnaires. The method used for sampling in this study is the non-probability convenience sampling method. The SEM-based multivariate approaches, such as structural equation modeling and confirmatory factor analysis, were employed, and the SmartPLS 3.0 software was used for the data evaluation. The respondents were selected through convenience sampling to generate the responses of individual online consumers who buy luxury goods online. The sample size was 364 and it was taken from a simple random table with a 5\% margin of error and a 95\% confidence level, as suggested by Saunders et al. (2007). The data was collected through structured questionnaires from the respondents from August 2018 to December 2018. We floated a total of 364 questionnaires, which were adequately filled, thus in this way, the response rate was $100 \%$, which was considered to be an excellent sample. As for the structure of the data samples concerned, there were 165 males and 199 females, in which 155 respondents were from the age bracket of 15-24 years old, 131 from the age bracket of 25-34, 55 respondents were from the age bracket of 35-44 years old, the rest of 23 respondents were from the age bracket of more than 45 years old. As far as the income of the respondents concerned, it was taken in Pakistani Rupee, out of all 364 respondents, $13.7 \%$ had an income between 20,000 to $40,000,29.2 \%$ had an income between 41,000 to $60,000,19.2 \%$ respondents had an income of $61,000-80,000$, while $37.9 \%$ had an income of $80,000+$. In terms of the education of respondents, out of 364 respondents, $44.8 \%$ of respondents had done their Master's degree, $45.9 \%$ of respondents had a Bachelor's degree, 5.5\% had education of Matric or O-levels, and 3.8\% had done their intermediate or A-levels.

\section{RESULTS AND DISCUSSION}

\subsection{Validity and Reliability}

To examine the validity, Criterion validity was ensured through a literature review, and an academic expert tested the Face validity. For this study, the data was collected from 364 participants with a $100 \%$ response rate. After the collection of data, it was coded into nominal variable and scale variables. The overall reliability was tested along with the reliability of each construct separately. Table 1 shows that the composite reliability $(>0.60)$, Cronbach alpha $(>0.70)$, and AVE $(>0.50)$ for each construct are within the acceptable range, which shows that the tool used for checking the hypothesis is reliable (Chatfield, 2018; Ahmed et al., 2020).

Tab. 1 - Validity and Reliability. Source: own research

\begin{tabular}{|l|l|l|l|}
\hline & Cronbach's Alpha & Composite Reliability & (AVE) \\
\hline Brand Image & 0.870 & 0.906 & 0.658 \\
\hline Brand Loyalty & 0.742 & 0.854 & 0.662 \\
\hline Cause Promotion & 0.769 & 0.896 & 0.811 \\
\hline Cause-Related Marketing & 0.799 & 0.882 & 0.715 \\
\hline Community Volunteering & 0.816 & 0.916 & 0.845 \\
\hline Corporate Philanthropy & 0.752 & 0.859 & 0.672 \\
\hline
\end{tabular}




\begin{tabular}{|l|l|l|l|}
\hline Corporate Social Mkt & 0.847 & 0.907 & 0.766 \\
\hline Socially Responsible BP & 0.835 & 0.883 & 0.655 \\
\hline
\end{tabular}

\subsection{Discriminant Validity through Fornell-Locker test}

The Discriminant validity ensures that a constructed measure is empirically unique and correct, which is a pre-requisite for employing structural equation modeling. Without discriminant validity, "constructs may influence the variation of observed variables that are theoretically associated." The criteria for ensuring discriminant validity through Fornell \& Larcker (1981) test was the value above 0.70 (Chatfield, 2018). All of the values of the discriminant validity have reported the values of above 0.70 (diagonal values). It can be seen that discriminant validity in the current study is ensured, as shown in Table 2.

Tab. 2 - Discriminant Validity. Source: own research

\begin{tabular}{|c|c|c|c|c|c|c|c|c|}
\hline & $\begin{array}{l}\text { Brand } \\
\text { Image }\end{array}$ & $\begin{array}{l}\text { Brand } \\
\text { Loyalty }\end{array}$ & \begin{tabular}{|l} 
Cause \\
Promo- \\
tion
\end{tabular} & $\begin{array}{l}\text { Cause- } \\
\text { Related } \\
\text { Market- } \\
\text { ing }\end{array}$ & $\begin{array}{l}\text { Com- } \\
\text { munity } \\
\text { Volun- } \\
\text { teering } \\
\end{array}$ & $\begin{array}{l}\text { Cor- } \\
\text { porate } \\
\text { Philan- } \\
\text { thropy } \\
\end{array}$ & $\begin{array}{l}\text { Cor- } \\
\text { porate } \\
\text { Social } \\
\text { Mkt } \\
\end{array}$ & $\begin{array}{l}\text { Socially } \\
\text { Re- } \\
\text { sponsi- } \\
\text { ble BP }\end{array}$ \\
\hline $\begin{array}{l}\text { Brand Im- } \\
\text { age }\end{array}$ & 0.811 & & & & & & & \\
\hline $\begin{array}{l}\text { Brand } \\
\text { Loyalty }\end{array}$ & 0.746 & 0.813 & & & & & & \\
\hline $\begin{array}{l}\text { Cause Pro- } \\
\text { motion }\end{array}$ & 0.569 & 0.446 & 0.901 & & & & & \\
\hline $\begin{array}{l}\text { Cause- } \\
\text { Related } \\
\text { Marketing }\end{array}$ & 0.552 & 0.519 & 0.582 & 0.845 & & & & \\
\hline $\begin{array}{l}\text { Commu- } \\
\text { nity Volun- } \\
\text { teering }\end{array}$ & 0.416 & 0.404 & 0.377 & 0.540 & 0.919 & & & \\
\hline $\begin{array}{l}\text { Corporate } \\
\text { Philan- } \\
\text { thropy }\end{array}$ & 0.662 & 0.539 & 0.544 & 0.395 & 0.385 & 0.820 & & \\
\hline $\begin{array}{l}\text { Corporate } \\
\text { Social Mkt }\end{array}$ & 0.550 & 0.579 & 0.529 & 0.698 & 0.597 & 0.516 & 0.875 & \\
\hline $\begin{array}{l}\text { Socially } \\
\text { Responsi- } \\
\text { ble BP }\end{array}$ & 0.691 & 0.647 & 0.535 & 0.670 & 0.721 & 0.518 & 0.678 & 0.809 \\
\hline
\end{tabular}

\subsection{Common Method Bias Testing}

The data received from the respondents may contain biases that are tested through two ap- 
proaches, as mentioned by Kim et al. (2013). First, by examining the correlation shown in Table 2 , if any correlation is greater or equal to 0.9 , it is a piece of strong evidence for biases in the data. The correlation's highest value is 0.746 , which is less than 0.9 , and the indicating common bias is less likely to exist. Second, the approach requires the inner VIF values of the constructs < 3.3 (Kock, 2015; Ahmed et al., 2019), Table 3 indicates the inner VIF values for all relationships among constructs $<3.3$, showing that common bias is less likely to exist (Kock, 2015; Kock \& Lynn, 2012).

Tab. 3 - Common Method Bias Testing. Source: own research

\begin{tabular}{|l|l|l|}
\hline Brand Image & Brand Image & Brand Loyalty \\
\hline Brand Loyalty & 2.046 & \\
\hline Cause Promotion & 1.870 & 1.869 \\
\hline Cause-Related Marketing & 2.525 & 2.513 \\
\hline Community Volunteering & 2.268 & 2.195 \\
\hline Corporate Philanthropy & 1.794 & 1.676 \\
\hline Corporate Social Mkt & 2.649 & 2.569 \\
\hline Socially Responsible BP & 3.289 & 3.107 \\
\hline
\end{tabular}

\subsection{Model Fit}

The model fit is the tested ability of the statistical model to conform to the set of observations defined in that particular statistical model through the goodness of fit (Chatfield, 2018). Table 4 exhibits the goodness of fit indices.

Tab. 4 -The model fitness. Source: own research

\begin{tabular}{|l|l|l|}
\hline & Saturated Model & Estimated Model \\
\hline SRMR & 0.073 & 0.073 \\
\hline d_ULS & 2.219 & 2.219 \\
\hline d_G1 & 1.318 & 1.318 \\
\hline d_G2 & 1.041 & 1.041 \\
\hline Chi-Square & 684.132 & 684.132 \\
\hline NFI & 0.918 & 0.918 \\
\hline
\end{tabular}

Since there are many criteria to ensure the model fitness, SmartPLS 3.0 offers measures which include Standardized Root Mean Square Residual (SRMR), Euclidean distance (D_ULS), geodesic distance (D_G), Root mean squared residual (RMS) and Normed Fit Indices (NFI). According to values of the first three criteria SRMR (lower than 0.08), D_ULS (P>0.05), and D_G ( $\mathrm{P}>0.05)$, the current model is considered highly fit, as the values meet the defined threshold. RMS criteria are applied to check the goodness of fit of the outer model, which can be avoided. The minimum value of NFI is considered to be above 0.90 , but if its value lies below 0.90 , it is suggested to check the non-normed fit indices value (NNFI). SmartPLS 3.0 has a limitation that the NNFI value cannot be calculated (Hussain et al., 2019). Therefore, it can be seen that the 
model fit has been ensured for the current study through the different model fit indices offered by SmartPLS 3.0.

\subsection{Variance explanation and path analysis}

The R-Square is the amount of variance each independent variable contributes to the variance of the dependent variable (Chatfield, 2018). The adjusted R-Square is R-Square, which has been adjusted after adding several variables in the model. The minimum 0.10 value of $\mathrm{R}$-square should be presented to explain the variance between the dependent and independent variables. However, according to Ahmed et al. (2019) the PLS-SEM, R-Square value of 0.7, 0.33, and 0.19 is considered to be reliable, moderate, and weak, as shown in Table 5.

Tab. 5 - Variance Explanation. Source: own research

\begin{tabular}{|l|l|l|}
\hline & R Square & R Square Adjusted \\
\hline Brand Image & 0.712 & 0.700 \\
\hline Brand Loyalty & 0.511 & 0.494 \\
\hline
\end{tabular}

Here the adjusted R-Square indicates that brand loyalty has a $51.1 \%$ variation, whereas brand image has a $70 \%$ variation caused by the framework.

The structural model of this study was summarized in the final findings to conclude the final decision of either accepting and rejecting the hypothesis; the Bootstrapping procedure was applied with the help of SmartPLS 3.0 by creating 5,000 sub-samples for the current study. The final results of the analysis are presented in Table 6 .

Tab. 6 - Path Analysis, Source: own research

\begin{tabular}{|l|l|l|l|}
\hline & Original Sample $(\mathrm{O})$ & T statistics & P Values \\
\hline Brand Loyalty $\rightarrow$ Brand Image & 0.394 & 6.231 & 0.000 \\
\hline Cause Promotion $\rightarrow$ Brand Image & 0.114 & 2.193 & 0.011 \\
\hline Cause Promotion $\rightarrow$ Brand Loyalty & -0.022 & 0.255 & 0.799 \\
\hline Cause-Related Marketing $\rightarrow$ Brand Image & 0.078 & 1.036 & 0.300 \\
\hline Cause-Related Marketing $\rightarrow$ Brand Loyalty & 0.076 & 0.895 & 0.371 \\
\hline Community Volunteering $\rightarrow$ Brand Image & -0.113 & 1.550 & 0.121 \\
\hline Community Volunteering $\rightarrow$ Brand Loyalty & 0.189 & 2.577 & 0.010 \\
\hline Corporate Philanthropy $\rightarrow$ Brand Image & 0.279 & 3.749 & 0.000 \\
\hline Corporate Philanthropy $\rightarrow$ Brand Loyalty & 0.241 & 2.814 & 0.005 \\
\hline Corporate Social Mkt $\rightarrow$ Brand Image & -0.085 & 1.035 & 0.301 \\
\hline Corporate Social Mkt $\rightarrow$ Brand Loyalty & 0.197 & 2.025 & 0.043 \\
\hline Socially Responsible BP $\rightarrow$ Brand Image & 0.317 & 3.563 & 0.000 \\
\hline Socially Responsible BP $\rightarrow$ Brand Loyalty & 0.486 & 4.743 & 0.000 \\
\hline
\end{tabular}




\section{DISCUSSION}

The results of this study confirmed the impact of various CSR initiatives on brand image with the mediation effect of brand loyalty on the influencing path. The individual results demonstrated that brand loyalty positively influenced brand image. These findings are consistent with previous studies, such as work by Tellefsen \& Thomas (2005) and Domi et al. (2019). The study further demonstrated that CSR has a positive and significant impact on brand image. Previous literature, such as Almeida \& Coelho (2019), has also reached similar views. However, the results show that the cause promotion did not have a significant influence on brand loyalty. These results are in line with the previous literature (Ahmed et al., 2019). A few studies have demonstrated contradictory results, i.e. a significant influence of promotion on brand loyalty (Domi et al., 2019; Medzhybovska \& Lew, 2019). A possible reason for these dissimilarities is the use of different approaches regarding cause promotion and brand loyalty. The outcomes of this study further exhibited that cause-related marketing did not have a significant impact on brand loyalty and brand image. Nevertheless, previous literature has demonstrated mixed results regarding this matter, e.g. Ahmed et al. (2020), and García-Fernández et al. (2018). Green \& Peloza (2011) had similar results, although Servera-Francés \& Arteaga-Moreno (2015) indicate different opinions. The results of this study also demonstrate that community volunteering did not have a significant influence on brand image. Previous literature has exhibited mixed results regarding the impact of community volunteering on brand image, with previous studies (Dyck et al., 2019; Ferreira \& Oliveira, 2014) demonstrating similar results. However, previous literature has also pointed out the positive and significant influence of community volunteering on brand image (Ahmed et al., 2020; Luo \& Bhattacharya, 2006; Martínez et al., 2013). The results of our study also exhibited that community volunteering had a positive and significant influence on brand loyalty; these results are consistent with previous literature, such as Jeon \& An (2019). Our outcomes have further demonstrated that corporate philanthropy had a positive and significant influence on brand image and brand loyalty. Previous literature also advocated similar findings and confirmed that corporate philanthropy had a significant influence on both brand image and brand loyalty (Peloza \& Shang, 2011). However, corporate social marketing did not have a significant impact on the brand image as per our findings, with similar outcomes indicated in previous studies, such as Grigoruta et al. (2019) and Ahmed et al. (2019). The present study has demonstrated that corporate social marketing had a positive and significant influence on brand loyalty. These findings are consistent with the previous literature, such as Lu et al. (2020), Sharma \& Jain (2019), Singh \& Saini (2016), Suki \& Suki (2019). Finally, our outcomes have demonstrated that socially responsible business practice had a significant and positive influence on brand image and brand loyalty, with these results replicated in previous literature such as Loosemore \& Lim (2018), Irshad et al. (2017).

Corporate Social Responsibility is an important aspect of all firms. It is extremely important for consumers as well as other stakeholders. Corporate brand strategies should take community wellbeing into account. Corporate social responsibility plays an important role in building a brand and brand identity. Consumers might recall a brand that is involved in CSR activities as opposed to another brand that is not involved in CSR. Consumers are becoming more skeptical about the promises of firms in different areas, including environmental policies, ethical business practices, 
and social responsibility. Insights of consumers into CSR are a big concern for strategy makers and marketers (Lu et al., 2020; Jeon \& An, 2019; Sharma \& Jain, 2019).

\section{CONCLUSION}

The main findings of this study have revealed that consumers do in fact recognize what CSR is. Furthermore, the majority of consumers know that CSR is one of the important aspects of firms. The main outcome of our study is that CSR initiatives have positive effects on brand loyalty and brand image which can increase the competitiveness of the firms in the market. Brand loyalty is a vital criterion for the position of firms in the marketplace as well as for creating competitive edges. Thus, companies should adopt necessary CSR initiatives so that they can sustain and maintain their brand loyalty as well as their brand image. This particular study can show firms and marketers ways to comprehend the impact of their CSR programs and how the different initiatives and programs can affect various dimensions of brand loyalty. This information can be used by strategy makers and marketers to formulate their strategies in accordance with these findings.

Finally, new multinationals that are in the process of establishing their business in Pakistan can also use this research as a part of formulating their strategies in other countries of the world, such as countries or regions along the BRI route proposed by China. In the future, the results of this study can be supplemented by targeting different populations and dimensions such as the impact of CSR on employee retention, the reputation of firms, etc.

Acknowledgement

This work was supported by the program Innovative Talents of Higher Education Institutions of Shanxi (PTIT) under Grant 20191043; the Planning Program for Philosophy and Social Sciences of Shanxi under Grant No. W20191020; the Key R\&D Program of Shanxi Province, China (Social Development) under Grant 201903D321004; as well as Taiyuan University of Science \& Technology Scientific Research Initial Funding (TYUST SRIF) under Grants No. W20182014 and No.W20192003.

\section{References}

1. Abbes, I., Hallem, Y., \& Taga, N. (2020). Second-Hand Shopping and Brand Loyalty: The Role of Online Collaborative Redistribution Platforms. Journal of Retailing and Consumer Services, 52, 1-11. https://doi.org/10.1016/j.jretconser.2019.101885

2. Ahmed, R. R., Hussain, S., Pahi, M. H., Usas, A., \& Jasinskas, E. (2019). Social Media Handling and Extended Technology Acceptance Model (ETAM): Evidence from SEM-Based Multivariate Approach. Transformation in Business \& Economics,18 (3), 246-271.

3. Ahmed, R. R., Vveinhardt, J., Warraich, U. A., Hasan, S. S. U., \& Baloch A. (2020). Customer Satisfaction \& Loyalty and Organizational Complaint Handling: Economic Aspects of Business Operation of Airline Industry. Inzinerine Ekonomik_Engineering Economics,31 (1), 114-125. https://doi.org/10.5755/j01.ee.31.1.8290

4. Almeida, M. D. G. M. C., \& Coelho, A. F. M. (2019). The Antecedents of Corporate Reputation and Image and Their Impacts on Employee Commitment and Performance: The Moderating Role of CSR. Corporate Reputation Review, 22 (1), 10-25. https://doi.org/10.1057/ s41299-018-0053-8 
5. Arbouw, P., Ballantine, P., \& Ozanne, L. (2019). Sustainable Brand Image: An Examination of Ad-Brand Incongruence. Marketing Intelligence \& Planning, 37 (5), 513-526. https://doi. org/10.1108/MIP-08-2018-0307

6. Asmussen, C. G., \& Fosfuri, A. (2019). Orchestrating Corporate Social Responsibility in the Multinational Enterprise. Strategic Management Journal, 40 (6), 894-916. https://doi.org/10.1002/ smj.3007

7. Chatfield, C. (2018). Introduction to Multivariate Analysis. London: Routledge.

8. Chen, H. H. (2018). More employees should be guided to participate in voluntary service. China Social Work, 6.

9. Cheung, M. L., Pires, G., \& Rosenberger, P. J. (2019). Developing a Conceptual Model for Examining Social Media Marketing Effects on Brand Awareness and Brand Image. International Journal of Economics and Business Research, 17 (3), 243. https://doi.org/10.1504/ IJEBR.2019.098874

10. Dawood, H. (2019). Influence of Perceived Corporate Social Responsibility on Brand Image, Satisfaction, and Trust. The Lahore Journal of Business, 7 (2), 33-58.

11. Dennis, C., Bourlakis, M., Alamanos, E., Papagiannidis, S., \& Brakus, J. J. (2017). Value CoCreation through Multiple Shopping Channels: The Interconnections with Social Exclusion and Well-Being. International Journal of Electronic Commerce, 21 (4), 517-547. https://doi.org/10.10 80/10864415.2016.1355644

12. Domi, S., Keco, R., Capelleras, J. L., \& Mehmeti, G. (2019). Effects of Innovativeness and Innovation Behavior on Tourism SMEs Performance: The Case of Albania. Economics \& Sociology, 12 (3), 67-85. https://doi.org/10.14254/2071-789X.2019/12-3/5

13. Dyck, A., Lins, K. V., Roth, L., \& Wagner, H. F. (2019). Do Institutional Investors Drive Corporate Social Responsibility? International Evidence. Journal of Financial Economics, 131 (3), 693-714. https://doi.org/10.1016/j.jfineco.2018.08.013

14. Feng, W., Wang, T., Qin, J., \& Wei, H. (2019). The Influence of Charitable Cause Promotion on the Negative Effect of Promotion. Management Review, 31 (1). http://doi.org/10.14120/j.cnki. cn11-5057/f.2019.01.012

15. Ferreira, P., \& de Oliveira, E.R. (2014). Does Corporate Social Responsibility Impact on Employee Engagement? Journal of Workplace Learning, 26 (3/4), 232-247. http://doi. org/10.1108/JWL-09-2013-0070

16. Fornell, C., \& Larcker, D. F. (1981). Structural Equation Models with Unobservable Variables and Measurement Error: Algebra and Statistics. Journal of Marketing Research, 18 (3), 382-388. https://doi.org/10.1177/002224378101800313

17. García-Fernández, J., Gálvez-Ruiz, P., Vélez-Colon, L., Ortega-Gutiérrez, J., \& FernándezGavira, J. (2018). Exploring Fitness Centre Consumer Loyalty: Differences of Non-Profit and Low-Cost Business Models in Spain. EconomicResearch-Ekonomska Istraživanja, 31 (1), 1042-1058. https://doi.org/10.1080/1331677X.2018.1436455

18. Green, T., \& Peloza, J. (2011). How does Corporate Social Responsibility Create Value for Consumers? Journal of Consumer Marketing, 28 (1), 48-56. https://doi. org/10.1108/07363761111101949 
19. Grigoruta, M. V. B., Neculaesei, A. N., Tatarusanu, M., Anastasiei, B., \& Ionescu, A. M. (2019). A Model of the Relationship between Organizational Culture, Social Responsibility, and Performance. Transformations in Business \& Economics, 18 (2), 489-509.

20. Hew, J. J., Lee, V. H., Ooi, K. B., \& Lin, B. (2016). Mobile Social Commerce: The Booster for Brand Loyalty? Computers in Human Behavior, 59, 142-154. https://doi.org/10.1016/j. chb.2016.01.027

21. Howie, K. M., Yang, L., Vitell, S. J., Bush, V., \& Vorhies, D. (2018). Consumer Participation in Cause-Related Marketing: An Examination of Effort Demands and Defensive Denial. Journal of Business Ethics, 147 (3), 679-692. https://doi.org/10.1007/s10551-015-2961-1

22. Hussain, S., Qazi, S., Ahmed, R. R., Veinhardt, J., \& Štreimikienė, D. (2019). Innovative User Engagement and Playfulness on Adoption Intentions of Technological Products: Evidence from SEM-Based Multivariate Approach. Economic Research-Ekonomska Istrą̌ivanja, 32 (1), 555-577.https://doi.org/10.1080/1331677X.2018.1558086

23. Iglesias, O., Markovic, S., Singh, J. J., \& Sierra, V. (2019). Do Customer Perceptions of Corporate Services Brand Ethicality Improve Brand Equity? Considering the Roles of Brand Heritage, Brand Image, and Recognition Benefits. Journal of Business Ethics, 154, 441-459. https://doi.org/10.1007/s10551-017-3455-0

24. Irshad, A., Rahim, A., Khan, M. F., \&Khan, M. M. (2017). The Impact of Corporate Social Responsibility on Customer Satisfaction and Customer Loyalty, Moderating Effect of Corporate Image. City University Research Journal, 63-73.

25. Ismail, A. R. (2017). The Influence of Perceived Social Media Marketing Activities on Brand Loyalty: The Mediation Effect of Brand and Value Consciousness. Asia Pacific Journal of Marketing and Logistics, 29 (1), 129-144. https://doi.org/10.1108/APJML-10-2015-0154

26. Jeon, M. A., \& An, D. (2019). A Study on the Relationship between Perceived CSR Motives, Authenticity, and Company Attitudes: A Comparative Analysis of Cause Promotion and Cause-Related Marketing. Asian Journal of Sustainability and Social Responsibility, 4 (1), 1-14. https://doi.org/10.1186/s41180-019-0028-4

27. Jia, W. (2019). Influence of Brand Image on Consumers' Purchase Intention: Evidence from the Apparel Industry of China. Modern Marketing, (5), 100-102.

28. Kaur, H., Paruthi, M., Islam, J., \& Hollebeek, L. D. (2020). The Role of Brand Community Identification and Reward on Consumer Brand Engagement and Brand Loyalty in Virtual Brand Communities. Telematics and Informatics, 46, 1-12. https://doi.org/10.1016/j. tele.2019.101321

29. Kim, Y. H., Kim, D. J., \& Wachter, K. (2013). A Study of Mobile User Engagement (MOEN): Engagement Motivations, Perceived Value, Satisfaction, and Continued Engagement Intention. Decision Support Systems, 56, 361-370. https://doi.org/10.1016/j.dss.2013.07.002

30. Kock, N. (2015). Common Method Bias in PLS-SEM: A Full Collinearity Assessment Approach. International Journal of e-Collaboration, 11 (4),1-10.

31. Kock, N., \&Lynn, G. (2012). Lateral Collinearity and Misleading Results in Variance-Based SEM: An Illustration and Recommendations. Journal of Association for Information Systems, 13 (7). 
32. Kotler, P., Keller, K. L., Ang, S. H., Tan, C. T., \& Leong, S. M. (2018). Marketing Management: An Asian Perspective. London: Pearson.

33. Kotler, P., \& Lee, N. (2004). Corporate Social Responsibility: Doing the Most Good for Your Company and Your Cause. New York: Wiley.

34. Kotler, P., \& Lee, N. (2005). Best of Breed: When It Comes to Gaining a Market Edge While Supporting a Social Cause, "Corporate Social Marketing" Leads the Pack. Social Marketing Quarterly, 11 (3), 91-103. https://doi.org/10.1080/15245000500414480

35. Lake, W., \& Conduit, J. (2016). How Social Marketing Can Address the Obesity Issue: The Role of Corporate Reputation. In Looking Forward, Looking Back: Drawing on the Past to Shape the Future of Marketing, 391. Switzerland: Springer, Cham.

36. Leckie, C., Nyadzayo, M. W., \& Johnson, L. W. (2016). Antecedents of Consumer Brand Engagement and Brand Loyalty. Journal of Marketing Management, 32 (5), 558-578. https://doi.or g/10.1080/0267257X.2015.1131735

37. Li, C., Qin, X., \& Zhao, H. (2017). An Empirical Research on the Factors that Affect Tourism Destination Brand Loyalty and Overall Impression: Evidence from Changji Region in Xinjiang. Management Review, 29 (7), 82-92. https://doi.org/10.14120/j.cnki.cn115057/f.2017.07.005

38. Lins, K. V., Servaes, H., \& Tamayo, A. (2017). Social Capital, Trust, and Firm Performance: The Value of Corporate Social Responsibility during the Financial Crisis. The Journal of Finance, 72 (4), 1785-1824. https://doi.org/10.1111/jofi.12505

39. Liu, Y. (2014). A Comparative Study of Commercial Sponsorship's and Charitable Donations' Respective Impacts on the Corporate Image and Product Evaluation. Southwestern University of Finance and Economics (Doctoral dissertation).

40. Liu, Y., \& Zhou, Z. (2015). The Relationships between Employees' Perceived Corporate Social Responsibility, Affective Commitment, and Organizational Citizenship Behavior: A CrossLevel Analysis of Commitment-Based Human Resource Management Practices. Management Review, 27 (10), 118-127. https://doi.org/10.14120/j.cnki.cn11-5057/f.2015.10.013

41. Loosemore, M., \& Lim, B. T. H. (2018). Mapping Corporate Social Responsibility Strategies in the Construction and Engineering Industry. Construction Management and Economics, 36 (2), 67-82. https://doi.org/10.1080/01446193.2017.1326616

42. Loureiro, S. M. C., Sarmento, E. M., \& Bellego, G. L. (2017). The Effect of Corporate Brand Reputation on Brand Attachment and Brand Loyalty: Automobile Sector. Cogent Business \& Management, 4 (1), 131-136. https://doi.org/10.1080/23311975.2017.1360031

43. Lu, J., Ren, L., Qiao, J., Lin, W., \& He, Y. (2019). Female Executives and Corporate Social Responsibility Performance: A Dual Perspective of Differences in Institutional Environment and Heterogeneity of Foreign Experience. Transformations in Business \& Economics, 18 (2), 174-196.

44. Lu, J., Ren, L., Zhang, C., Wang, C., Ahmed, R. R., \& Streimikis, J. (2020). Corporate Social Responsibility and Employees' Behavior: Evidence from Mediation and Moderation Analysis. Corporate Social Responsibility and Environmental Management, 2020; 1-20. https://doi.org/10.1002/ csr.1919 
45. Luo, G. F. (2015). Analysis of the Effect of Public Service Advertising on Consumers' Consumption Behavior: Evidence from a Natural Field Experiment. Commercial Times, (12), 72-74. https://doi.org/10.3969/j.issn.1002-5863.2015.12.029

46. Luo, X., \& Bhattacharya, C. B. (2006). Corporate Social Responsibility, Customer Satisfaction, and Market Value. Journal of Marketing, 70 (4), 1-18. https://doi.org/10.1509/jmkg.70.4.001

47. Luo, X., \& Jiang, M. H. (2019). Content Marketing, Brand Identity, and Consumer Brand Loyalty. Commercial Times, 73-76.

48. Luo, Z., \& Lv, L. (2019). The Influence of Cause-Related Marketing on Consumers' Attitude and Its Theoretical Explanation. Advances in Psychological Science, 27 (4), 737-747. https://doi. org/10.3724/SP.J.1042.2019.00737

49. Mabkhot, H. A., Shaari, H., \& Salleh, S. M. (2017). The Influence of Brand Image and Brand Personality on Brand Loyalty, Mediating by Brand Trust: An Empirical Study. Jurnal Pengurusan, 50, 71-82. https://doi.org/10.17576/pengurusan-2017-50-07

50. Martínez, P., \& del Bosque, I. R. (2013). CSR and Customer Loyalty: The Roles of Trust, Customer Identification with the Company, and Satisfaction. International Journal of Hospitality Management, 35, 89-99. https://doi.org/10.1016/j.ijhm.2013.05.009

51. Medzhybovska, N., \& Lew, A. (2019). Micro Businesses Participation in Public Procurement: Evidence from Ukraine. Economics \& Sociology, 12 (3), 98-113.https://doi.org/10.14254/2071789X.2019/12-3/7

52. Mody, M., Day, J., Sydnor, S., Lehto, X., \& Jaffé, W. (2017). Integrating Country and Brand Images: Using the Product-Country Image Framework to Understand Travelers' Loyalty towards Responsible Tourism Operators. Tourism Management Perspectives, 24, 139-150. https:// doi.org/10.1016/j.tmp.2017.08.001

53. Nan, X., \& Heo, K. (2007). Consumer Responses to Corporate Social Responsibility (CSR) Initiatives: Examining the Role of Brand-Cause Fit in Cause-Related Marketing. Journal of Advertising, 36 (2), 63-74. https://doi.org/10.2753/JOA0091-3367360204

54. Nguyen, N., \& Leblanc, G. (2001). Corporate image and corporate reputation in customers' retention decisions in services. Journal of Retailing and Consumer Services, 8 (4), 227-236. https:// doi.org/10.1016/S0969-6989(00)00029-1

55. Nickerson, C., \& Goby, V. P. (2016). From Philanthropy to Broader Social Engagement: Muslim Consumers' Response to Corporate Social Marketing Strategies in Dubai. Journal of Islamic Marketing, 7 (4), 423-440. https://doi.org/10.1108/JIMA-02-2015-0017

56. Ogba, I., \& Tan, Z. (2009). Exploring the Impact of Brand Image on Customer Loyalty and Commitment in China. Journal of Technology Management in China, 4 (2), 132-144. https://doi. org/10.1108/17468770910964993

57. Özbağ, G. K. (2018). The Breath of Life: From Philanthropy to Global Corporate Citizenship. In. Managerial Strategies for Business Sustainability During Turbulent Times, 258-276. Pennsylvania: IGI Global.

58. Pappu, R., \&Quester, P. G. (2016). How does Brand Innovativeness Affect Brand Loyalty? European Journal of Marketing, 50 (1/2), 2-28. https://doi.org/10.1108/EJM-01-2014-0020 
59. Park, E., Kim, K. J., \& Kwon, S. J. (2017). Corporate Social Responsibility as a Determinant of Consumer Loyalty: An Examination of Ethical Standard, Satisfaction, and Trust. Journal of Business Research, 76, 8-13. https://doi.org/10.1016/j.jbusres.2017.02.017

60. Peloza, J., \& Shang, J. (2011). How can Corporate Social Responsibility Activities Create Value for Stakeholders? A Systematic Review. Journal of the Academy of Marketing Science, 39 (1), 117-135. https://doi.org/10.1007/s11747-010-0213-6

61. Penguin Intelligence. (2019). Smart Phones \& Smart Hardware: Report on Purchasing Power of Chinese Netizens in 2019. Retrieved from: http://www.199it.com/archives/858933.html

62. Plewa, C., Conduit, J., Quester, P.G., \& Johnson, C. (2015). The Impact of Corporate Volunteering on CSR Image: A Consumer Perspective. Journal of Business Ethics, 127 (3), 645-659. https://doi.org/10.1007/s10551-014-2066-2

63. Ramli, A. H. (2017). Patient Satisfaction, Hospital Image, and Patient Loyalty in West Sulawesi Province. Business and Entrepreneurial Review, 17 (1). http://doi.org/10.25105/ber.v16i2.5088

64. Sattayawaksakul, D., Cote, J. A., \& Tiangsoongnern, L. (2019). Consumer Evaluations of Co-Branding: Analyzing the Relationship of Brand Image Consistency, Brand Personality Similarity, Brand Extension Authenticity, and the Congruency between For-Profit and NonProfit Parent Brand. TNI Journal of Business Administration and Languages, 7 (1), 19-26.

65. Saunders, M., Lewis, P., \& Thornhill, A. (2007). Research Methods for Business Students (4th Ed). New Jersey: Prentice-Hall.

66. Sen, S., Du, S., \& Bhattacharya, C. (2016). Corporate Social Responsibility: A Consumer Psychology Perspective. Current Opinion in Psychology, 10, 70-75. https://doi.org/10.1016/j. copsyc.2015.12.014

67. Servera-Francés, D., \& Arteaga-Moreno, F. (2015). The Impact of Corporate Social Responsibility on the Customer Commitment and Trust in the Retail Sector. Ramon Llull Journal of Applied Ethics, 6 (6),161-178.

68. Shabbir, M. Q., Khan, A. A., \& Khan, S. R. (2017). Brand Loyalty Brand Image and Brand Equity: The Mediating Role of Brand Awareness. International Journal of Innovation and Applied Studies, 19 (2), 416-423.https://doi.org/10.1080/1331677X.2018.1547202

69. Sharma, R., \& Jain, V. (2019). CSR, Trust, Brand Loyalty, and Brand Equity: Empirical Evidences from Sportswear Industry in the NCR Region of India. Metamorphosis: A Journal of Management Research, 18 (1), 57-67. https://doi.org/10.1177/0972622519853158

70. Singh, J., \& Saini, S. (2016). Managing Consumer Loyalty through Acquisition, Retention, and Experience Efforts: An Empirical Study on Service Consumers in India. Vision, 20(2), 121134. https://doi.org/10.1177/0972262916637264

71. Suki, N. M., \& Suki, N. M. (2019). Correlations between Awareness of Green Marketing, Corporate Social Responsibility, Product Image, Corporate Reputation, and Consumer Purchase Intention. In Corporate Social Responsibility: Concepts, Methodologies, Tools, and Applications, 143-154. Pennsylvania: IGI Global.

72. Sürücü, Ö., Öztürk, Y., Okumus, F., \& Bilgihan, A. (2019). Brand Awareness, Image, Physical Quality, and Employee Behavior as Building Blocks of Customer-Based Brand Equity: Consequences in the Hotel Context. Journal of Hospitality and Tourism Management, 40, 114-124. https://doi.org/10.1016/j.jhtm.2019.07.002 
73. Szőcs, I., Schlegelmilch, B. B., Rusch, T. \& Shamma, H. M. (2016). Linking Cause Assessment, Corporate Philanthropy, and Corporate Reputation. Journal of the Academy of Marketing Science, 44, 376-396.https://doi.org/10.1007/s11747-014-0417-2

74. Taodocs. (2018). Analysis of Consumer Brand Loyalty. Retrieved from: https://www.taodocs. $\mathrm{com} / \mathrm{p}-140808040 . \mathrm{html}$

75. Tellefsen, T., \& Thomas, G. P. (2005). The Antecedents and Consequences of Organisational and Personal Commitment in Business Service Relationships. Industrial Marketing Management, 34 (1), 23-37. https://doi.org/10.1016/j.indmarman.2004.07.001

76. Tian, M., Li, C. Q., \& Chen, Y.N. (2016). Influence of Corporate Philanthropic Behavior on Consumer Response. Enterprise Economy, 7, 41-48. https://doi.org/10.13529/j.cnki.enterprise. economy.2016.07.007

77. Westberg, K., \& Pope, N. (2014). Building Brand Equity with Cause-Related Marketing: A Comparison with Sponsorship and Sales Promotion. Journal of Marketing Communications, 20 (6), 419-437. https://doi.org/10.1080/13527266.2012.723025

78. Wu, S. I., \& Wang, W. H. (2014). Impact of CSR Perception on Brand Image, Brand Attitude, and Buying Willingness: A Study of a Global Café. International Journal of Marketing Studies, 6 (6), 43-56. https://doi.org/10.5539/ijms.v6n6p43

79. Yang, K., Yang, H., Chang, W., \& Chine, H. (2017). The Effect of Service Quality among Customer Satisfaction, Brand Loyalty, and Brand Image. https://ieeexplore.ieee.org/abstract/ document/8290299

80. Yang, N., \& Yin, S. (2019). Research on the Socialization Path of Virtual Brand Community Members: A Double Intermediate Perspective of Satisfaction and Identity. Journal of Xi'an University of Finance and Economics, 32 (6), 103-110. https://doi.org/10.19331/j.cnki. jxufe.2019.06.013

81. Yeh, C. H., Wang, Y., \& Yieh, K. (2016). Predicting Smartphone Brand Loyalty: Consumer Value and Consumer-Brand Identification Perspectives. International Journal of Information Management, 36 (3), 245-257. https://doi.org/10.1016/j.ijinfomgt.2015.11.013

82. Yuan, H., \& Tian, H. (2015). Influence of Corporate Charitable Donations on Consumer Brand Attitude: Moderating Effect of Fit and Affinity. Management Review, 27 (12), 110-119. https://doi.org/10.14120/j.cnki.cn11-5057/f.2015.12.011

83. Zhang, G., Yi, C., \& Hu, Q. (2015). Corporate Social Responsibility Behavior and Channel Conflict: The Mediating Effect of Social Network Resources. East China Economic Management, 29 (4), 1-9. https://doi.org/10.3969/j.issn.1007-5097.2015.04.001

84. Zhang, Q., He, S., \& Shi, X. (2015). The Relationship between Corporate Social Responsibility and Employees' OI-An Organizational Pride Mediation CSR Attributions of Moderating Mechanism. Management Review, 27 (2), 111-119. https://doi.org/10.14120/j.cnki.cn115057/f.2015.02.011

85. Zheng, Z. (2014). Empirical Study on the Effects of Corporate Public Welfare Marketing on the New Consumers' Brand Attitude and Purchase Intentions-Take Lenovo for Example. Master's thesis, Qingdao: Ocean University of China.

86. Zhou, Y., \& Lu, J. (2011). Volunteer Activity of Firms: An Effective Way to Implement CSR. Enterprise Economy, (3), 152-155. http://doi.org/10.13529/j.cnki.enterprise.economy.2011.03.032 


\section{Contact information}

Prof. Jintao Lu, Ph.D. (Corresponding author)

Taiyuan University of Science and Technology

China

School of Economics and Management/Research Center for Corporate Social Responsibility

China

E-mail:lut2002@163.com

ORCID: 0000-0001-9331-1411

Prof. Licheng Ren, M.D.

Taiyuan University of Science and Technology

China

School of Economics and Management/Research Center for Corporate Social Responsibility

E-mail:rlc2000@sina.com

ORCID: 0000-0002-0967-4445

Associate. Prof. Chong Zhang, M.D.

Taiyuan University of Science and Technology

School of Economics and Management

China

E-mail:lucyfinance@sina.com

ORCID: 0000-0002-3425-8179

Chunyan Wang, Postgraduate Student

Taiyuan University of Science and Technology

School of Economics and Management

Department of Business Administration

China

E-mail:wangchunyancg@163.com

ORCID: 0000-0001-6629-410X

Zabra Shabid, Ph. D. Student

Shaheed Zulfikear Ali Bhutto Institute of Science and Technology

Pakistan

Email:zw_29@botmail.com

Justas Streimikis Ph.D. Student

Lithuanian Institute of Agrarian Economics Vilnius

Lithuania

University of Economics and Human Science in Warsan

Poland

E-mail:justas.streimikis@gmail.com

ORCID: 0000-0003-2619-3229 